\title{
UPAYA PENINGKATAN PERSONAL HIGIENE ORGAN REPRODUKSI PEREMPUAN SANTRI PONDOK PESANTREN UMMUL QURO SALOPA
}

\author{
OLEH: \\ Hariyani Sulistyoningsih, Sinta Fitriani \\ STIKes Respati \\ (yanstia_77@yahoo.co.id )
}

\section{A. DASAR PEMIKIRAN}

Kesehatan reproduksi remaja merupakan kondisi kesehatan yang menyangkut masalah kesehatan organ reproduksi, yang kesiapannya dimulai sejak usia remaja ditandai oleh haid pertama kali pada remaja perempuan atau mimpi basah bagi remaja laki-laki. Kesehatan reproduksi remaja meliputi fungsi, proses, dan sistem reproduksi remaja. Sehat yang dimaksudkan tidak hanya semata-mata bebas dari penyakit atau dari cacat saja, tetapi juga sehat baik fisik, mental maupun sosial (Harnani et al., 2015).

Masalah kesehatan diusia remaja merupakan salah satu masalah penting dalam siklus kehidupan. Masalah kesehatan diusia dewasa sebagian berkaitan dengan perilaku kesehatan ataupun gaya hidup di usia muda termasuk di usia remaja. Perilaku hidup sehat sejak usia dini merupakan salah satu upaya yang cukup penting dalam menciptakan sumber daya manusia yang produktif dan berkualitas di masa yang akan datang. Beberapa perilaku berisiko pada usia remaja diantaranya adalah kebiasaan merokok, gizi tidak seimbang,kurang aktifitas fisik, hygiene dan sanitasi individu, depresi/stress, konsumsi obat-obatan terlarang dan konsumsi minuman beralkohol.

Masa remaja sebagai titik awal proses reproduksi menunjukkan persiapan strategi intervensi perlu dimulai jauh sebelum masa usia subur. Nilai anak perempuan dan anak laki-laki dalam keluarga dan masyarakat, dan bagaimana perlakuan yang mereka terima merupakan faktor penting yang turut menentukan kesehatan reproduksi mereka dimasa mendatang. Perubahan fisik, psikis, dan emosi remaja pada masa pubertas dapat membuat remaja lebih ekspresif dalam mengeksplorasi organ kelamin dan perilaku seksualnya. Sementara itu, pengetahuan dan persepsi yang salah tentang seksualitas dan kesehatan reproduksi dapat menyebabkan remaja berperilaku berisiko terhadap kesehatan reproduksinya dan juga memiliki masalah kesehatan reproduksi yang tentauya akan berpengaruh pada status kesehatan pada fase kehidupan berikutnya. Oleh karena itu, peran orang tua dan guru menjadi penting dalam mendampingi remaja mencari dan menemukan informasi kesehatan reproduksi yang tepat.

Kesehatan reproduksi juga masih merupakan salah satu masalah kesehatan diusia remaja. Survei yang dilakukan oleh World Health Organisation menunjukkan bahwa remaja putri usia 10-14 tahun memiliki permasalahan kesehatan reproduksi berupa iritasi. Sebanyak 43,3 juta remaja putri Indonesia mengalami dan gatal pada daerah genitalia. Penelitian yang dilakukan oleh Suwandono, dkk di Jawa Tengah, Jawa Timur, dan Bali, menunjukkan bahwa $65 \%$ orang tua remaja, $83.3 \%$ guru sekolah, dan $77.3 \%$ remaja mempunyai pengetahuan yang kurang, dalam hal perkembangan reproduksi remaja, perubahan psikologis dan emosional remaja, penyakit menular seksual dan abortus.

Remaja putri menjadi hal yang difokuskan karena organ reproduksi perempuan lebih kompleks daripada laki-laki dan risiko kesehatan yang ditimbulkannya juga lebih banyak (Juliana et al., 2018).

Upaya promosi dan pencegahan masalah kesehatan reproduksi juga perlu diarahkan pada masa remaja atau peralihan dari masa anak menjadi dewasa, dimana perubahan-perubahan dari bentuk dan fungsi tubuh terjadi dalam waktu relatif cepat. Remaja perlu dibekali 
informasi seputar kesehatan reproduksi dan berbagai faktor yang mungkin memengaruhi sistem reproduksi. agar remaja tidak melakukan hal-hal yang berisiko memberikan efek negatif terhadap kesehatan organ reproduksinya. Sehingga pengenalan tentang cara menjaga organ reproduksi sudah harus dilakukan sejak usia remaja.

SMA-IT Ummul Quro Salopa adalah salah satu SMA yang menerapkan system pendidikan berbasis pesantren. Siswa menempuh pendidikan dengan sistem boarding (menetap) di pondok yang disediakan. Selain mendapatkan materi pembelajaran yang berdasarkan kurikulum pendidikan KTSP, para siswa juga dibekali pembelajaran yang berkaitan dengan ilmu agama. Dalam proses pendidikan dan aktifitas keseharian dilakukan pemisahan antara siswa laki-laki dan perempuan. Selama ini siswa belum pernah mendapatkan informasi khusus terkait kesehatan reproduksi dan juga belum pernah dilakukan pengukuran terkait pengetahuan dan sikap juga personal higiene siswa dalam kesehatan reproduksi. Sehubungan dengan

hal tersebut, dirasakan perlu melakukan upaya penyuluhan untuk meningkatkan pengetahuan santri perempuan terkait personal higiene organ reproduksi sebagai upaya mencapai derajat kesehatan reproduksi yang optimal bagi para siswa perempuan.

\section{B. TUJUAN}

1. Tujuan Umum:

Kegiatan ini bertujuan untuk meningkatkan pengetahuan santri di SMAIT Ummul Quro Salopa tentang personal higiene organ reproduksi perempuan khususnya remaja siswa.

\section{Tujuan Khusus:}

Tujuan khusus dari kegiatan adalah melakukan penyebarluasan informasi dalam rangka meningkatkan pengetahuan santri tentang organ reproduksi, fungsi, dan cara menjaganya sehingga timbul kesadaran untuk menerapkan perilaku sehat dalam menjaga kesehatan organ reproduksi.

\section{BENTUK KEGIATAN}

Kegiatan pengabdian masyarakat dalam bentuk pemberian penyuluhan dengan metode ceramah ini merupakan tindak lanjut dari penelitian yang telah dilakukan sebelumnya. Pemaparan dilakukan dengan media power point dan alat bantu infocus. Materi yang disampaikan meliputi organ reproduksi perempuan, fungsi, dan cara menjaganya,serta permasalahan kesehatan pada organ reproduksi perempuan. Selain pemamparan materi, kegiatan juga diselingi dengan tanya jawab.

\section{SASARAN}

Sasaran kegiatan ini adalah seluruh remaja putri, siswa SMA IT Ummul Quro yang merupakan santri di Pondok Pesantren Ummul Quro Salopa, sebanyak 100 orang.

\section{E. TEMPAT DAN WAKTU}

Kegiatan dilaksanakan di halaman masjid Akhwat Pondok Pesantren Ummul Quro Salopa pada hari Jum'at, tanggal 24 Januari 2020, pukul 10.00-12.30 WIB.

\section{F. PELAKSANA}

Pelaksana kegiatan ini adalah dua orang dosen tetap Program Studi Kesehatan Masyarakat. Terdapat pembagian tugas sebagai pelaksana kegiatan yaitu dalam mempersiapkan dan memaparkan materi, serta berkoordinasi dengan pihak pesantren dalam hal pelaksanan kegiatan

juga mendokumentasikan kegiatan yang berlangsung, untuk selanjutnya bersamasama menyusun laporan kegiatan,

\section{$\begin{array}{lll}\text { G.HASIL KEGIATAN DAN } & \end{array}$ PEMBAHASAN}

Kegiatan dilaksanakan dalam dua tahap yaitu penyampaian materi dengan metode ceramah selama 30 menit dan dilanjutkan 
dengan tanya jawab. Peserta sangat antusias menyimak materi yang dipaparkan, hal ini ditunjukkan dengan banyaknya pertanyaan yang diajukan dan harus dilakukan pembatas jumlah pertanyaan dikarenakan waktu yang disediakan oleh sekolah tidak akan mencukupi untuk menampung seluruh pertanyaan yang diajukan.

Penyuluhan kesehatan adalah kegiatan pendidikan yang dilakukan dengan menyebarkan informasi-informasi, pesan, menanamkan keyakinan, sehingga masyarakat sadar, tahu dan mengerti, tetapi juga mau dan mampu melakukan anjuran yang ada hubungannya dengan kesehatan sehingga terjadi peningkatan pengetahuan, keterampilan, dan sikap (Notoadmojo, 2012). Tujuan penyuluhan kesehatan adalah tercapainya perubahan perilaku individu, keluarga dan masyarakat dalam membina dan memelihara kesehatan, berperan aktif mewujudkan kesehatan yang optimal sesuai hidup sehat baik fisik, mental dan sosial. Salah satu metode yang digunakan dalam memberikan penyuluhan adalah ceramah, yaitu menerangkan dan menjelaskan suatu ide, pengertian atau pesan secara lisan kepada kelompok sasaran. Metode ceramah dapat diselingi dengan pertanyaan, dan dibantu menggunakan alat peraga, baik langsung maupun tiruan serta melakukan demonstrasi untuk menerangkan konsep yang dijelaskan dan melakukan gaya ceramah yang bervariasi.

Hal yang harus diperhatikan dalam memberikan penyuluhan agar tujuan yang diharapkan bisa tercapai diantaranya adalah persiapan, penguasaan materi, serta penyampaian penyuluhan yang menarik dengan menggunakan bahasa yang mudah dimengerti dan dipahami. Selain itu dalam memberikan penyuluhan juga harus memperhatikan waktu, tempat, serta jumlah sasaran yang disesuaikan dengan lokasi kegiatan penyuluhan agar proses dalam penyuluhan berjalan dengan baik (Effendy, 2007).
Pemberian penyuluhan tentang kesehatan organ reproduksi perempuan diharapkan dapat meningkatkan pengetahuan dan menumbuhkan kesadaran untuk mempraktikan pemeliharaan kesehatan reproduksi organ reproduksi, khususnya bagi remaja. Pengetahuan remaja tentang peersonal higiene organ reproduksi juga masih terbatas. Penelitian terhadap 42 santri putri di Pesantren Modern Babun Najah Ulee Kareng kota Banda Aceh Tahun 2019 menunjukkan bahwa santri yang memiliki pengetahuan baik tentang personal higinene organ reproduksi hanya $57,1 \%$ dan sisanya masih memiliki pengetahuan kurang (Kurnian sih Putri, n.d.). Demikian juga penelitian di SMA Advent Bitung Provinsi Sulawesi Utara menunjukkan bahwa masih terdapat $20,7 \%$ siswi memiliki pengetahuan yang kurang terkait personal higiene organ reproduksi (Gamis, 2018).

Remaja putri perlu menjaga kebersihan organ reproduksi dengan baik yang dimulai dari memperhatikan kebersihan diri, terlebih Indonesia merupakan daerah yang beriklim tropis. Udara panas dan cenderung lembab sering membuat banyak berkeringat dibagian tubuh yang tertutup dan lipatan-lipatan kulit, seperti didaerah alat kelamin. Kondisi ini menyebabkan mikroorganisme jahat mudah berkembang biak yang akhirnya bisa menimbulkan infeksi (Pudiastuti, 2012). Informasi yang perlu diketahui remaja putri terkait organ reproduksi diantaranya adalah bagaiamana menjaga organ kewanitaan pada saat menstruasi, cara membersihkan organ kewanitaan setelah buang air, serta memilih pakaian dalam yang tepat yang dapat menjaga kelembaban daerah kewanitaan (Eny, 2012).

\section{H. KESIMPULAN DAN SARAN}

Kegiatan pengabdian masyarakat yang dilakukan mendapatkaan respon positif dari sasaran sehingga tujuan kegiatan ini diharapkan dapat tercapai. Sebanyak 100 orang santri remaja putri di SMAIT Ummul Quro Salopa mendapatkan informasi yang tepat tentang personal higiene organ reproduksi perempuan 
sehingga dapat menerapkan perilaku yang sehat.

Selanjutnya kegiatan pengabdian masyarakat yang dilakukan dapat berupa pembentukan kader remaja peduli kesehatan reproduksi yang nantinya berperan dalam memastikan seluruh remaja putri di pondok pesantren menerapkan perilaku yang mendukung reproduksi sehat. Kader remaja ini berperan sebagai teman sebaya yang dapat memberikan dorongan positif dalam merubah perilaku remaja.

\section{DAFTAR PUSTAKA}

Effendy, O. U. (2007). Ilmu Komunikasi: Teori dan Praktek. Remaja Rosdakarya.

Eny, K. (2012). Kesehatan Reproduksi Remaja dan Wanita. Salemba Medika.

Gamis, D. G. A. L. (2018). DETERMINAN PERSONAL HYGIENE ORGAN REPRODUKSI EKSTERNA WANITA DI SMA ADVENT BITUNG PROVINSI SULAWESI UTARA TAHUN 2018. Universitas Hasanudin.

Harnani, Y., Marlina, H., \& Elmia, K. (2015). Kesehatan Reproduksi (Untuk Mahasiswa Ilmu Kesehatan Masyarakat). Deepublish.

Juliana, M. I., Rahmayanti, M. D., \& Astika, M. E. (2018). TINGKAT PENGETAHUAN DAN SIKAP SISWA SMP TENTANG KESEHATAN REPRODUKSI REMAJA BERDASARKAN KEIKUTSERTAAN PADA PROGRAM PUSAT INFORMASI DAN KONSELINGREMAJA (PIK-R). Dunia Keperawatan, 6(2).

https://doi.org/10.20527/dk.v6i2.5556

Kurnian sih Putri, M. (n.d.). PENGETAHUAN REMAJA PUTRI TERHADAP

\begin{tabular}{l|c} 
PERSONAL & \multicolumn{3}{c}{ HYGIENEORGAN } \\
REPRODUKSI | sih | Jurnal Ilmiah \\
Mahasiswa Fakultas
\end{tabular}

Retrieved September 30, 2020, from http://www.jim.unsyiah.ac.id/FKep/article/vi ew/12213

Notoadmojo, S. (2012). Promosi Kesehatan dan Perilaku Kesehatan. Rineka Cipta.

Pudiastuti, R. D. (2012). 3 Fase Penting pada Wanita (Menarche, Menstruasi, dan Menopause). Elex Media Komputindo.

\section{J. DOKUMENTASI}
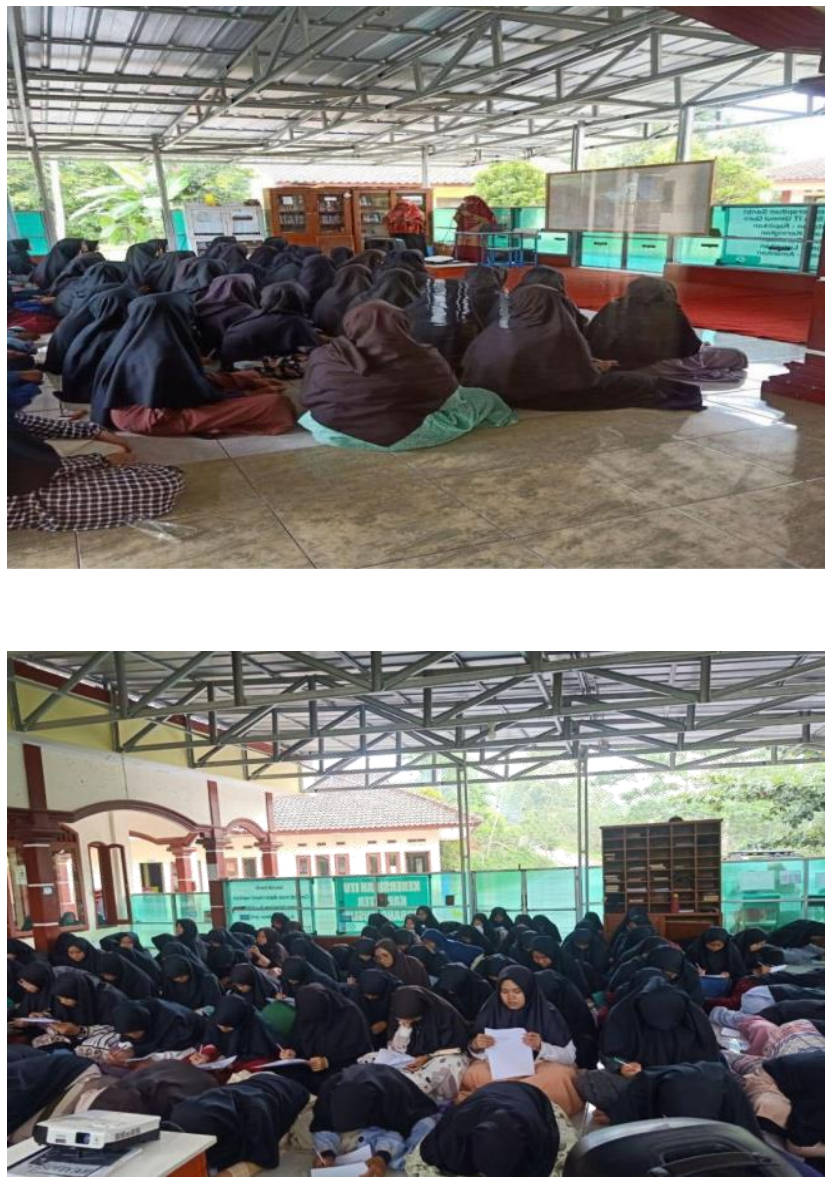